\title{
Multidisciplinary Characterization of Mine Water from a Former Uranium Mine for Bioremediation Purposes.
}

\author{
ANTONIO M. NEWMAN-PORTELA SR. ${ }^{1,2}$, EVELYN \\ KRAWCZYK-BÄRSCH ${ }^{2}$, MARGARITA LOPEZ- \\ FERNANDEZ $^{1}$, FRANK BOK ${ }^{2}$, ANDREA KASSAHUN $^{3}$, \\ JOHANNES RAFF ${ }^{2}$ AND MOHAMED L. MERROUN ${ }^{4}$ \\ ${ }^{1}$ Department of Microbiology, University of Granada \\ ${ }^{2}$ Institute of Resource Ecology, Helmholtz-Zentrum Dresden- \\ Rossendorf \\ ${ }^{3}$ WISMUT GmbH \\ ${ }^{4}$ Department of Microbiology, Faculty of Sciences, University of \\ Granada
}

Presenting Author: antnewpor@ugr.es

In Saxony and Thuringia (Germany), an intensive uranium mining took place for decades until 1990. After the stop of the mining activities, the mines have been flooded for remediation purposes, which continues in many mines to this day. The resulting release of the soluble $U$ into the mine water represents a major health risk. Remediation approaches using indigenous microbial communities are an efficient strategy. In this study, we have characterized the microbial diversity and geochemistry of water from two German former uranium mines (SchlemaAlberoda and Pöhla) to design a bioremediation approach.

ICP-MS and Ion-Chromatography studies showed that the mine waters exhibited a higher concentration of $U$, sulfate, iron and manganese in Schlema-Alberoda compared to that of Pöhla (U: 1.01 and $0.11 \mathrm{mg} / \mathrm{L}$, sulfate: 335 and $0.26 \mathrm{mg} / \mathrm{L}$, iron: 0.99 and $0.13 \mathrm{mg} / \mathrm{L}$ and manganese: 1.44 and $0.16 \mathrm{mg} / \mathrm{L}$, respectively). The 16S and ITS1 rRNA gene analyses of both mine waters revealed a high microbial diversity. The total bacterial community composition combining both mine waters indicated an average relative abundance of sulfate-reducing-bacteria (e.g., Sulfuricuvum 9.5\%, Sulfurimonas $4.5 \%$ and Sulfurovum $6.5 \%$ ) and iron-oxidizing-bacteria (e.g., Gallionella 3\%, Sideroxydans $3 \%$ ). These bacterial groups are reported to be involved in U(VI) reduction as a key process in the bioremediation of anoxic $\mathrm{U}$ contaminated sites. Therefore, to design bioremediation strategies for these U-contaminated waters, the SchlemaAlberoda water was used as a reference for setting anoxicmicrocosms. Concretely, U-reducing-bacteria were biostimulated by supplementing with glycerol $(10 \mathrm{mM})$ as electron donor. ICPMS and Ion-Chromatography analysis from the microcosms revealed a decrease of $U(\approx 89 \%)$, sulfate $(\approx 99 \%)$, iron $(\approx 86 \%)$ and manganese $(\approx 88 \%)$. In addition, a drop of Eh and $\mathrm{pH}$ of the system was detected. A thermodynamical Eh-pH predominance diagram was calculated by Geochemist's Workbench, indicating the formation of U(IV) precipitates, probably uraninite, after 3 months at the latest.

These results show that the $U$ enzymatic reduction of soluble $\mathrm{U}(\mathrm{VI})$ to insoluble $\mathrm{U}(\mathrm{IV})$, as uraninite, is favored by the addition of an electron donor (such as glycerol) in low concentrated Ucontaminated mine waters. Therefore, this strategy might be an efficient bioremediation approach relevant for U-contaminated 